\title{
What Determines Bond Market Development? New Theoretical Insights
}

Ameenullah Aman ${ }^{1}$

Asmadi Mohamed Naim

Mohamad Yazid Isa

Received 2019-01-09

Accepted 2019-01-10

Published 2019-01-10

Keywords

Bond market development, Theoretical relationship, Financial Crisis,

Foreign capital inflows

\section{How to cite?}

Aman, A., Naim, A., \& Isa, $M$. (2019). What Determines Bond Market Development? New Theoretical Insights. SEISENSE Journal of Management, 2(1), 99-106.

https:/ / doi.org/10.33215/sjom.v2i1.94
Islamic Business School (IBS UUM), UUM College of Business, University Utara Malaysia, Sintok, Malaysia

Islamic Business School (IBS UUM), UUM College of Business, University Utara Malaysia, Sintok, Malaysia

Islamic Business School (IBS UUM), UUM College of Business, University Utara Malaysia, Sintok, Malaysia

\begin{abstract}
Purpose- To diversify financing portfolio and reduce the reliance on the banking system, developing economies have realized the importance of bond market development. Bond markets facilitate economies to be more resilient towards the events of financial crises. Therefore, the share of the bond market in the financial system of the Asian economies has remarkably increased in the last decade. However, the academic literature on the bond market is very limited as compared to bank and equity markets. This was mainly because of the unavailability of vast data due to the absence of secondary markets for bonds in most of the economies. To fill this gap, this conceptual study postulates the theoretical relationships of bond market with various macroeconomic and financial factors. The study also assumes some new dimensions for bond financing and opens discussion for scholarly literature and empirical justifications. Design/Methodology- Content analysis approach is used to review relevant literature for the possible associations of bond market with macroeconomic and financial factors. Practical Implications- The theoretical relationships discussed in the paper need empirical testing in future research to conclude policy implications. If the relationship between foreign capital and bond securities is established with empirical justification, we draw the policy that concerned authorities need to create a suitable environment for the attraction of foreign capital to provide support to the development of domestic debt market.
\end{abstract}

Copyright (c) 2019 The Author(s)

(cc) BY

${ }^{1}$ Corresponding Author's email address: ameenullahaman.s@gmail.com 


\section{Introduction}

The importance of the development of bond market refers to the various aspects of the economy. Most importantly, the presence of the bond market in the economy reduces the over-reliance of sovereign and corporate entities on the banking system which makes them vulnerable to the financial crisis situation (Aman, Sharif, \& Arif, 2016; Bhattacharyay, 2013). In fact, the financial industry of the economy becomes more efficient with the availability of the bond market in the system (Mihaljek, Scatigna, \& Villar, 2002). Bond markets allow for portfolio diversification and handle the risks of exchange rate volatility, particularly for sovereign authorities, and maturity mismatch for corporate sectors.

Before the advent of bond markets, sovereign authorities used to rely on and force banking system to invest in sovereign papers which had the adverse effect of crowding out investments for corporate sectors. Also, the option of external borrowings by governments lead to the devaluation of local currency, hence, raises exchange rate volatility. Similarly, corporate borrowers had to seek short term bank financing even for long term projects which creates payment burdens and events of default. Therefore, countries realized the need of the bond markets to create more financing avenues in the economy. Notably, Das (2005) argued that the credit environment creates because of bond market leads to the improvement in corporate governance.

In addition, handling large capital inflows was a challenge for central banks before in the absence of bond markets. Issuing only short term central bank papers for money market operations derives interest rates for a shorter period and disturbs the structure of capital inflows ignoring the long term needs (Turner, 2002). Alternatively, bond markets enable issuers to issue a variety of securities in terms of period, structure and type of security. Also, bond markets attract more investors from local to foreign which enhance the competition in the market and allow the availability of financing in competitive rates.

Discussing the development phases of bond markets in Asia, Das (2005) records this development prior to the Asian financial crisis as well as after the said crisis period. Before the crisis, Korea was the corporate bond market leader with $32 \%$ of total corporate financing through the bond market (Davis \& Stone, 2004). Most of the other economies of Asia did not have a bond market before the Asian crisis because of lack of funds and demand as well as stringent regulations. However, after the episode of crisis, economies realized the importance of diversification and having bond markets to restructure banks and fulfill funding requirements for budget deficits (Das, 2005). In developing countries particularly, they do not only use bond financing to adjust fiscal deficits but also for current account deficits.

Accordingly, the development of the bond market was noticed by many developing countries, like Malaysia, Indonesia, and South Korea. Several steps were taken to support the issuance of bond securities, as the initiative of New Miyazawa Initiative (NMI) in the year 1999. Japan Bank of International Cooperation (JBIC) supported NMI initiative to provide Asian economies the interest rate guarantee for the issuance of bonds. Subsequently, Central banks of East Asia Pacific created a fund in 2003, Asian Bond Fund (ABF). The fund set aside USD 1billion under ABF-I to invest in the bonds issued by the sovereign authorities of member countries. Then in the year 2004, the forum of Asia-Pacific Economic Council (APEC) took an initiative of Asian Bond Market Initiative (ABMI) to provide support and handle the problems of Asian bond issuers as discussed by Ameer (2007). These all were the starting initiatives taken to foster the bond market in Asia and the market continues to spread in most of the economies of the region.

The academic literature on the determinants of the bond market is very limited. Most of the studies are directed to the banks or equity issues. It was because of two main reasons. First, the absence of secondary markets for bond financing in most parts of Asia. Therefore, the availability of data for bond securities had always remained a challenge. Second, the majority of the borrowing by sovereign and corporate sectors have remained inclined towards bank financing which made the development of the banking sector more relevant 
to the financial development in past. The limited available research on bonds does not cater the vast factors with relevance to bonds as they have been studied with relevance to the banks and equity issues. Therefore, to fill this gap, we contribute in the academic literature by discussing the theoretical foundations of various macroeconomic and financial factors in the context bonds. Considering the importance of capital inflows for the development of large bond markets, we also study the theoretical relationships between foreign capital inflows and bond market development. This study opens new discussion for the scholars on this novel topic and invites further empirical investigations. We also outline the possible policy implications coming out of these theoretical discussions.

\section{Literature Review}

Various studies have been conducted in the last decade to study the determinants of conventional bond markets (Adelegan \& Radzewicz-Bak, 2009; Ameer, 2007; BIS, 2002; Braun \& Briones, 2006; Burger \& Warnock, 2004; Fanta, 2017; Fink, Haiss, \& Hristoforova, 2003; Godlewski, Turk-Ariss, \& Weill, 2013; Herring \& Chatusripitak, 2000; Hristoforova, 2003; Kapingura \& Makhetha-Kosi, 2014; Mu, Phelps, \& Stotsky, 2013; Rudra P. Pradhan, Arvin, Bennett, Nair, \& Hall, 2016; Sharma, 2001; Thumrongvit, Kim, \& Pyun, 2013). Some of the studies find that macroeconomic factors play a significant role in the development of bond markets (Bondt, 2005; Korajczyk \& Levy, 2003; Park \& Shenoy, 2002). Particularly, the study, conducted by Eichengreen and Luengnaruemitchai (2004) with developed and developing countries sample, find that factors that contribute in the development of bond markets in Asia are large size of the economy, better institutions, less volatility in exchange rates and competitive environment of the banking system. On the contrary, the same finds large fiscal balance as negatively associated with bond markets. Similar kinds of results were also found by Eichengreen et al. (2008) in the study of Latin America. This study also found the positive relationship between exports and bond market development. Export-oriented countries have developed economies which is always attractive for investors.

Moreover, another study by Burger and Warnock (2006) on 49 domestic bond markets finds the positive role of reduced historical inflation rates on the growth of bond markets. This study also finds the same importance of institutions and the banking system for the bond market. These results are consistent with the study of Claessens et al. (2007). Similar macroeconomic results were found along with the positive role of law and order situation on bond markets by Adelegan and Radzewicz-Bak (2009). The study was conducted in 23 Sub-Saharan African countries with the sample of 1990-2008. Their study also found the negative impacts of low savings towards banking and bond markets.

In recent studies of Bhattacharyay (2013) in Asia and Mu et al. (2013) in Africa, findings complement the contributions of Eichengreen and Luengnaruemitchai (2004) that economic size, economic development, institutional environment, interest and exchange rates volatility, financial development and fiscal balance are the factors which have a strong association with bond market development. To support these few studies available on the topic, we extend below the theoretical postulation between macroeconomic, financial and foreign capital factors with bond market development. We also add some new dimensions in the literature which have not discussed before in the context of bond markets.

\section{Impact of Foreign Direct Investment on Bond Market Development}

There is always a positive relationship between financial development of foreign investments. Notably, foreign investment inflows particularly contribute to the development of the recipient country's bond market as discussed by (Bhattacharyay, 2013). Developing economies where there is large domestic demand for investment show more obvious association between foreign investments and bond market. On the contrary, it is possible that the foreign investment because of bond issues may not be directed to the bond market. 
Therefore, we postulate the ambiguous theoretical connection between foreign direct investment and bond market development. The unclear association needs further empirical explanations.

\section{Impact of Workers' Remittance on Bond Market Development}

It is well established in the literature that workers' remittance is associated with financial development of the recipient country (Aggarwal et al., 2006; Gupta et al., 2009). Also, the recipient country observes credit expansion because of remittance inflows which also play a role in financial development (Mundaca, 2005). Similarly, Chowdhury and Chowdhury (1992) conclude a positive association of remittances with investments. Durand et al. (1996) also find the association between remittances and increase in investments. This indicates the possibility of deployment of remittances for investments in the bond market. However, on the contrary, Massey and Parrado (1994) argue for the possibility that inflows of remittances do not accelerate investments, rather used for domestic utilization. This shows the unclear relationship of remittances with financial development, particularly with bond market development and needs empirical testing.

\section{Impact of Exports of Goods and Services on Bond Market Development}

The growth in the bond market is associated with the openness of the economy (Bhattacharyay, 2013). Local firms find difficult to deal with local competition if an economy is not open to outsiders. In bank oriented economies, particularly the developing world, the banking system considers bond securities as an alternate financial source for borrowers; therefore, banks resist the development of the market. The resistance from the banking sector becomes ineffective in an open economy with foreign competition (Rajan \& Zingales, 2003). Nevertheless, Adelegan and Radzewicz-Bak (2009) find that those economies are more dependent on the bond market as an alternative which is not considered open to cross border countries. Thus, we postulate the theoretical association between exports of goods and services and bond market development.

\section{Impact of Economic Size on Bond Market Development}

Economic size is very relevant to the bond market development. If a country has a smaller economic size, it does not have scale efficiencies which oppose the strength and liquidity in the bond market. Consequently, the bond market will be unable to issue global securities because of lack of demand from global investors for smaller issues (Mu et al., 2013). Similarly, large investment banks will not take part which will shatter the confidence of investors and investors will not be interested in long term holdings (Eichengreen \& Luengnaruemitchai, 2004). Therefore, we argue for a strong relationship between economic size and bond market.

\section{Impact of Economic Development on Bond Market Development}

The relationship between income per capita and financial development has already got some attention in the available literature (Mu et al., 2013). Higher income per capita increases the reliability of the contracts and ensures more rights for investors. Additionally, Institutions of the economy improve with higher per capita income. Macroeconomic volatility also reduces because of the better stage of economic development. Therefore, the stage of economic development is associated with bond market development.

\section{Impact of Interest Rates on Bond Market Development}

Uncertainty is not good for the economy. If interest rates highly fluctuate in the economy, investors lose confidence because of uncertainty. Therefore, holding the power of bond securities will be negatively affected because of risk diminishing purchasing power (Bhattacharyay, 2013). Moreover, investors will not be interested in long term bonds (Mu et al., 2013). Therefore, the impact of interest rate volatility on bond market development is negative. 


\section{Impact of Government Consumption Spending on Bond Market Development}

Investments in the economy influence because of government policies. If monetary authorities increase interest rates because of government consumptions, it will disappear the funds from the market could be invested in bond market securities and the demand for bonds will be negatively affected. However, Ndikumana (2000) argues for the positive role of government consumption in making the investment through the accelerating effect. Thus, we postulate the theoretical relationship between government consumption and the bond market.

\section{Impact of Current Account Balance on Bond Market Development}

National current account deficits lead to the issuance of more bond issues (Min, 1998; Sachs \& Williamson, 1985). Similarly, most commonly developing economies also issue bonds to support fiscal budget deficits. The decline in oil prices in the last few years reduced the income of Middle Easters economies which showed the issuance of enough Islamic and conventional bond issues. Therefore, we argue for an association between national current account balance and bond issues.

\section{Impact of Banking System on Bond Market Development}

Bond and banking markets are both basically debt markets. Therefore, both the markets primarily share the competition in the economy. Investors and borrowers consider bonds and banking as an alternative investment and financial avenues. Particularly, much of the dealings in bond securities are done through the banking system. Additionally, banking system serves as a marketer of bond issues. Therefore, banks are considered a contributing factor in the progress of the bond market. However, the banking industry is far elder and established than the bond market; therefore, banks have more power to take away the large market share from the bond financing (Mu et al., 2013). The association between the two debt markets is unclear and justifies empirical explanations.

\section{Impact of Equity Market on Bond Market Development}

Equity market plays various roles in the expansion of the bond market. Most importantly, the problem of information asymmetry is addressed by the equity market. Moreover, corporate governance improves because of equity issues which are good for corporate bond issues. Also, the cost of bond securities issuance goes down because of the already established equity market (Demirguc-Kunt \& Maksimovic, 1996). The knowledge of equity issues also helps investors and issuers to deal with bond issues (Smaoui, Mimouni, \& Temimi, 2017). Therefore, the equity market and bond market are supposed to be the complements.

\section{Conclusion}

Asian bond markets expanded and started to develop more promisingly after the Asian crisis 1997. Bond financing allows sovereign and corporate entities to have diversification in their financial portfolio which will make them more resilient to the crisis. However, the bond market did not get enough attention in the literature unlike the competitors, banking and equity markets. Many of the factors discussed in relation to banking or equity markets were ignored for the bond market. Therefore, this conceptual study postulated the theoretical foundations for bond market development with some less discussed and some new dimensions. The study contributed and opened some new discussion in the literature by discussing the relationships of various macroeconomic, financial and foreign capital factors with bond market development.

\section{Policy Implications}

The theoretical relationships discussed in the paper need empirical testing in future research to conclude policy implications. If the relationship between foreign capital and bond securities is established with 
empirical justification, we draw the policy that concerned authorities need to create a suitable environment for the attraction of foreign capital to provide support to the development of domestic debt market. Moreover, the role of various macroeconomic factors needs to be tested empirically in the context of bonds to harmonize the environment accordingly to smooth the bond market development. For instance, in order to maintain the confidence of investors in the local bond market, monetary policymakers need to endeavor for fewer fluctuations in the interest rates. Furthermore, it can be seen based on an empirical investigation that how financial sectors, like banking and stock, should be managed to create a favorable environment for the bond market.

\section{References}

Adelegan, O. J., \& Radzewicz-Bak, B. (2009). What Determines Bond Market Development in SubSaharan Africa? IMF Working Papers, 09(213), 1. https://doi.org/10.5089/9781451873603.001

Aggarwal, R., Demirguc-Kunt, A., \& Martinez Peria, M. S. (2006). Do workers' remittances promote financial development?. The World Bank.

Aman, A., Sharif, S., \& Arif, I. (2016). Comparison of islamic banks with conventional banks: Evidence from an emerging market. Journal of Management Sciences, 3(1), 24-33.

Ameer, R. (2007). What moves the primary stock and bond markets? Influence of macroeconomic factors on bond and equity issues in Malaysia and Korea. ASIAN ACADEMY of MANAGEMENT JOURNAL of ACCOUNTING and FINANCE, 3(1), 93-116.

Bhattacharyay, B. N. (2013). Determinants of bond market development in Asia. Journal of Asian Economics, 24, 124-137. https://doi.org/10.1016/j.asieco.2012.11.002

BIS. (2002). The development of bond markets in emerging economies. Bis. https://doi.org/10.2139/ssrn.1187575

Bondt, G. D. (2005). Determinants of corporate debt securities in the Euro Area. The European Journal of Finance, 11(6), 493-509.

Braun, M., \& Briones, I. (2006). The Development of Bond Markets around the World, (February).

Burger, J. D., \& Warnock, F. E. (2004). Foreign Participation in Local-Currency Bond Markets, (December).

Chowdhury, K., \& Chowdhury, M. (1992). Trade in labor services and its macroeconomic effects on a small economy: evidence from Bangladesh. In Proceedings of the 14th International Symposium on Asian Studies (Vol. 6, pp. 327-334).

Claessens, S., Klingebiel, D., \& Schmukler, S. L. (2007). Government bonds in domestic and foreign currency: the role of institutional and macroeconomic factors. Review of International Economics, 15(2), 370-413.

Das, D. K. (2005). Asian economy and finance: A post-crisis perspective. Ontario: Springer.

Davis, E. P., \& Stone, M. R. (2004). Corporate financial structure and financial stability. Journal of Financial Stability, 1(1), 65-91.

Demirguc-Kunt, A., \& Levine, R. (1996). Stock Markets, Corporate Finance, and Economic Growth - An Overview.pdf. The World Bank Economic Review. https://doi.org/10.2307/3990061

Durand, J., Kandel, W., Parrado, E. A., \& Massey, D. S. (1996). International migration and development in Mexican communities. Demography, 33(2), 249-264.

Eichengreen, B., \& Luengnaruemitchai, P. (2004). Why doesn't Asia have bigger bond markets? (No. w10576). National Bureau of Economic Research.

Eichengreen, B., Panizza, U., Borensztein, E., 2008. Prospects for Latin American bond markets: a crosscountry view. In: Borensztein, E., Cowan, K., Eichengreen, B., Panizza, U. (Eds.), Bond Markets in Latin America: On the Verge of a Big Bang? MIT Press, Cambridge, pp. 247-290. 
Fanta, A. B. (2017). Bond markets, stock markets, banks and growth: A system GMM analysis. Global Business and Economics Review, 19(1). https://doi.org/10.1504/GBER.2017.080779

Fink, G., Haiss, P., \& Hristoforova, S. (2003). Bond Markets and Economic Growth, 39(April), 1-35.

Godlewski, C. J., Turk-Ariss, R., \& Weill, L. (2013). Sukuk vs. conventional bonds: A stock market perspective. Journal of Comparative Economics, 41(3), 745-761. https://doi.org/10.1016/j.jce.2013.02.006

Gopinath, S. (2007). Development of Local Currency Bond Markets: The Indian Experience. Debt, Finance and Emerging Issues in Financial Integration, 1-26.

Gupta, S., Pattillo, C. A., \& Wagh, S. (2009). Effect of remittances on poverty and financial development in Sub-Saharan Africa. World development, 37(1), 104-115.

Herring, R. J., \& Chatusripitak, N. (2000). The case of the missing market: The bond market and why it matters for financial development.

Hristoforova, G. F. / P. H. / S. (2003). Bond Markets and Economic Growth. IEF Working Paper, (April), $1-31$.

Kapingura, F., \& Makhetha-Kosi, P. (2014). The Causal Relationship between the Bond Market Development and Economic Growth in Africa: Case Study of South Africa. Mediterranean Journal of Social Sciences, 5(3), 126-131. https://doi.org/10.5901/mjss.2014.v5n3p126

Korajczyk, R., \& Levy, A. (2003). Capital structure choice: Macroeconomic conditions and financial constraints. Journal of Financial Economics, 68(1), 75-109.

Matei, I. (2013). Government bond market linkages within EMU: Evidence from a multivariate Granger causality analysis. Economic Bulletin, 33(3), 1885---1898.

Massey, D. S., \& Parrado, E. (1994). Migradollars: The remittances and savings of Mexican migrants to the USA. Population Research and Policy Review, 13(1), 3-30.

Mihaljek, D., Scatigna, M., \& Villar, A. (2002). Recent trends in bond markets. BIS papers, (11), 13-41.

Min, H. G. (1998). Determinants of Emerging Market Bond Spread: Do Economic Fundamentals Matter?, (March).

Mu, Y., Phelps, P., \& Stotsky, J. G. (2013). Bond markets in Africa. Review of Development Finance, 3(3), 121-135. https://doi.org/10.1016/j.rdf.2013.07.001

Mundaca, B. G. (2009). Remittances, financial market development, and economic growth: the case of Latin America and the Caribbean. Review of Development Economics, 13(2), 288-303.

Ndikumana, L. (2000). Financial Determinants of Domestic Investment in Sub-Saharan Africa : Evidence from Panel Data, 28(2).

Park, J., \& Shenoy, C. (2002). An examination of the dynamic behavior of aggregate bond and stock issues. International Review of Economics and Finance, 11, 175- 189.

Pradhan, R. P., Arvin, M. B., Bennett, S. E., Nair, M., \& Hall, J. H. (2016). Bond Market Development, Economic Growth and Other Macroeconomic Determinants: Panel VAR Evidence. Asia-Pacific Financial Markets, 23(2), 175-201. https://doi.org/10.1007/s10690-016-9214-X

Pradhan, R. P., Zaki, D. B., Maradana, R. P., Dash, S., Jayakumar, M., \& Chatterjee, D. (2015). Bond market development and economic growth: The G-20 experience, 13(1), 51-65. https://doi.org/10.1016/j.tekhne.2015.09.003

Rajan, R., \& Zingales, L. (2003). Banks and Markets: The Changing Character of European Finance (No. 3865). CEPR Discussion Papers.

Sachs, J. D., \& Williamson, J. (1985). External debt and macroeconomic performance in Latin America and East Asia. Brookings Papers on Economic Activity, 1985(2), 523-573.

Sharma, K. (2001). The Underlying Constraints on Corporate Bond Market Development in Southeast Asia. World Development, 29(8), 1405-1419. https://doi.org/10.1016/S0305-750X(01)00043-2 
Smaoui, H., Mimouni, K., \& Temimi, A. (2017). Sukuk, Banking System, and Financial Markets : Rivals or Complements? Economics Letters. https://doi.org/10.1016/j.econlet.2017.09.014

Thumrongvit, P., Kim, Y., \& Pyun, C. S. (2013). Linking the missing market: The effect of bond markets on economic growth. International Review of Economics and Finance, 27, 529-541. https://doi.org/10.1016/j.iref.2013.01.008

Turner, P. (2002). Bond markets in emerging economies: an overview of policy issues. BIS papers, 11, 112. 